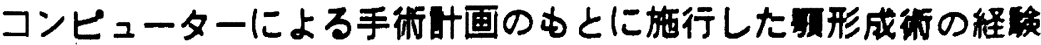 一小下识症症例—
}

\author{
兵行忠・眨虫忠
}

\section{Surgical correction of jaw deformity performed by operative plan using microcomputer system \\ - Report of micrognathia-}

Yukitada Hyo - Tadahiko IrzukA

は じめに

近年, 手術法や手術器具の進歩に伴って, 影顔面变形 症症例に対し，比較的容易に靧形成術を行らことができ るよらになってきた。しかし、これらの手術を施行する に漈して術前の十分な治瘄計画の作成か，手術結果の成 否を决定することはいらまでもない，

従来, 手術を行らのに, 頭部 $\mathbf{X}$ 線規格写真 (以下セ7 フロと記す)による診査と顥模型による娭討で，標準的 な形態に対する 当該症例の異常な部位を知り，また正 常咬合を得るに必要な頡の移動量について，模型上で Model surgeryを行い，さらにセファロより得られた概 形の Paper surgery で移動後の形眧の予測を行ってき た1).

先に著者らは多变量解析を用いて定旦的に下類前突症

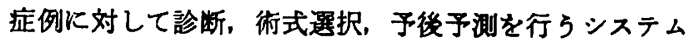
を開発し ${ }^{2)}$ たか，今回小下颗症症例に対して，マイクロ コンピューターシステムを用いて診断し，額骨の移動量 を決定し，手術計画を作成して影形成術を施行し良好な 結果を得た症例を経験したので，そのシステムの詳細を 報告する。

なお本症例は砒素ミルク中毒認定患者である.
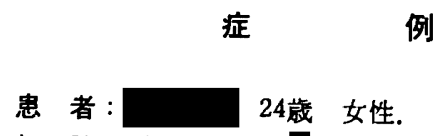

初 診: 昭和54年1月日。

主 訴: 小下顥症.

家族歴: 家族, 親族内に顔面变形を呈するるのは認め

京都大学医学部口腔外科学救室（主任：小野尊睦教 授）

Department of Oral and Maxillofacial Surgery, Faculty of Medicine, Kyoto University (Chief: Prof. Takatoki Ono)

受付日：昭和56年 1 月 14 日
られナ゙，他にす特砃を只なし。

既往愿: 满期正常分视で出应。生下時体后は $2,850_{\mathrm{B}}$

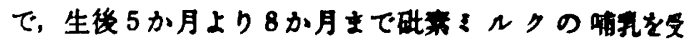

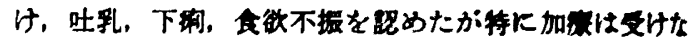
かった.

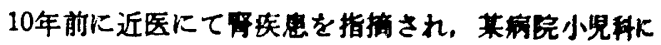

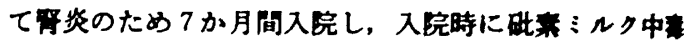

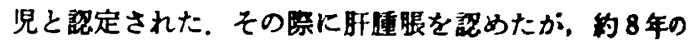
通院加恭にて里快している。

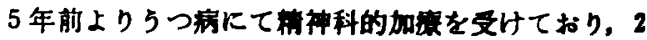
年前より卵策発青不全によりホルモン胡の投与を文けて いる.

現病歷：7〜8 年前より小下顥拉, いわゆる Bird face を旺するようになり，2〜3 年前より声が強く路めら

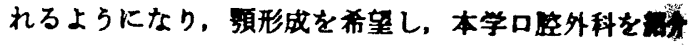
され，同年 4 月目入浣した。

現症:

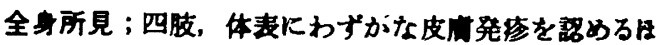
かに，体幹の骨格発青不全などの異营所見は証められな かった.

局所所見；側貌で明らかな下頭骨の発育不全を示し

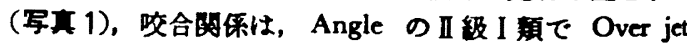
$10 \mathrm{~mm}$, Over bite $4 \mathrm{~mm}$ であった，梅牙は，数齿のう 齿を認めるほか，齿質の石灰化不全など齿牙の形成異赏 は認められない(军要 2).

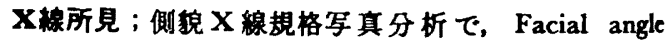
71. 46, Convexity 29.58, A-B plane -11.74, Y-Axis 75.98, SNB 76.83, SNA-SNB 12.74 と明らかな下頁 骨発费不全を認めた（写【3，図 1).

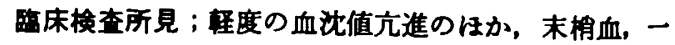

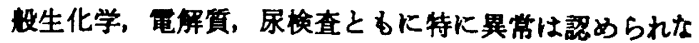
かった（表1）.

手術計画：側方セファロ写真をディジダィザ上で, 硬 組蟣18計测点を入力し，マイクロコンピューターにより $\mathrm{S}$ 点を原点とし， S-N 平面をX軸とする座醥に変找して 得られた Profilogram (図 2 ) と, 標淮困形との比效およ 


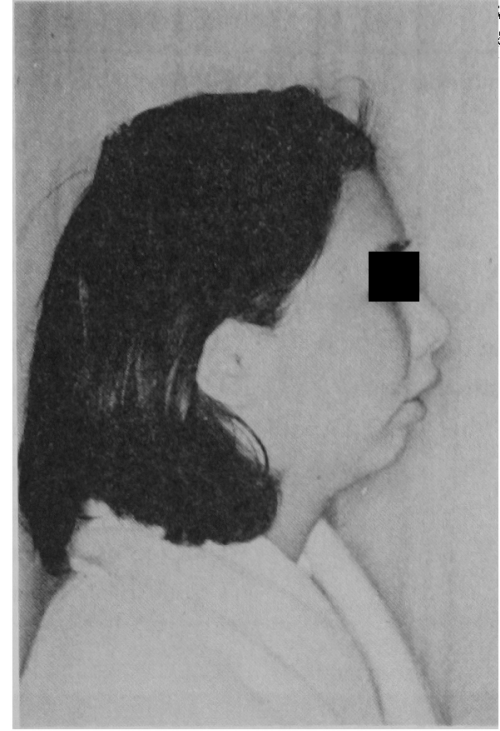

写真 1 入院時の测貌

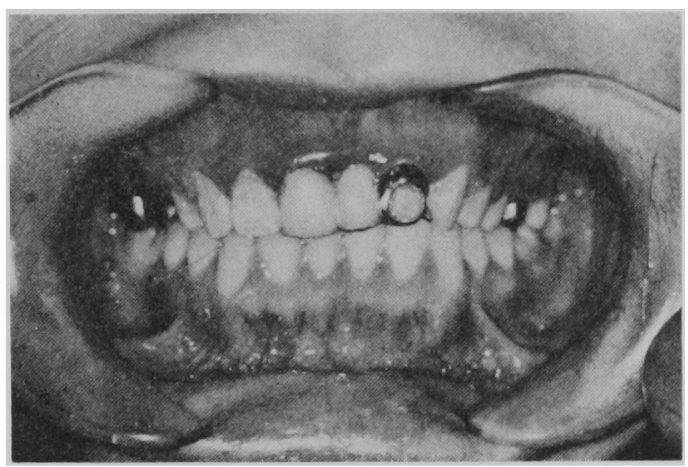

写真 2 入院時の咬合状態

び顎模型による検討により，9 mm の下顎骨全体の前方 への移動によって良好な咬合関係が得られることが判明 したが，いまだオトガイ部の突出感不足のために，Proflogram に上る分析で, $7 \mathrm{~mm}$ オトガイ 部を前方移動 することにより，満足すべき Profile が得られることを 確認した（図了）.

手術および経過：昭和54年 4 月⿴日，GOF 全麻下に 両側下顎枝矢状分割法(Obwegeser ${ }^{3)}$ 法)により下䂓骨全 体を $9 \mathrm{~mm}$ 前方に移動し, さらにオトガイ部の Horizontal osteotomy により $7 \mathrm{~mm}$ 前方にオトガイ部を Slide させる Genioplasty を施行した（図4).

術後の経過は良好で， 6 週間の額間固定を行い，下影 骨の前方移動および Genioplasty により，術後側貌は明 らかな改善を示し, 小下顥症特有の Profile は消失して いる(写真 4).

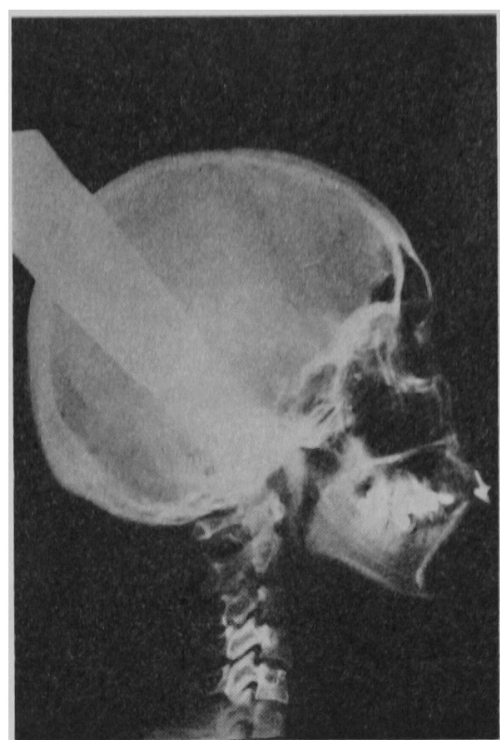

写枿 3 人院時の側方セファロ写真

ROENTEEN CEPHALOUETRIC ARALSIS

CASE No, CY Mame.S T

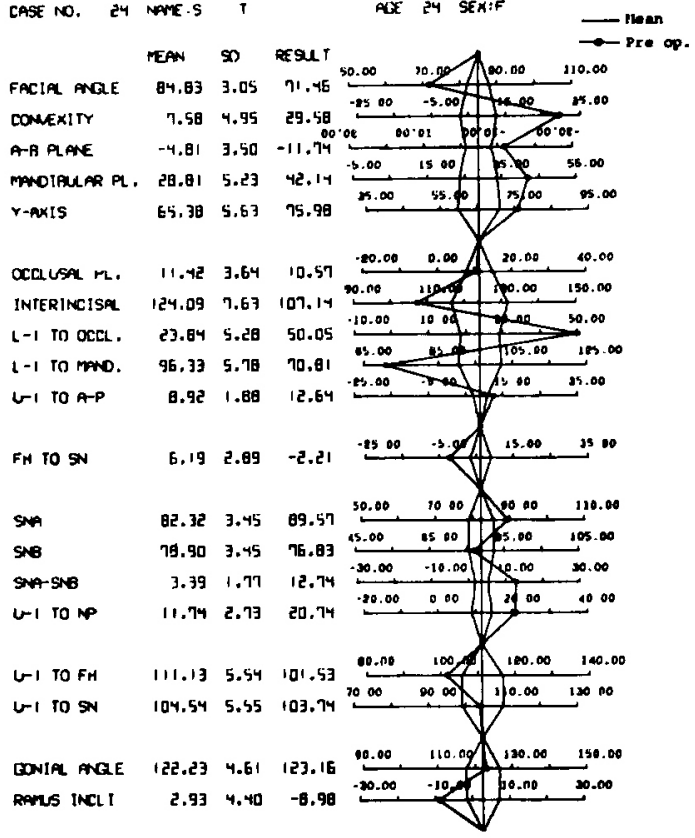

图 1 入院時のセファロ分析跕果

Profilogram でも術前に比して著しく改善し, 手術計 画とほほ同様の满足すべき所見を示している（图 5).

咬合関係むOver jet $2 \mathrm{~mm}$, Over bite $2 \mathrm{~mm}$ となり (写真 5), セファロ分析に拈いても, Facial angle 76.82, 


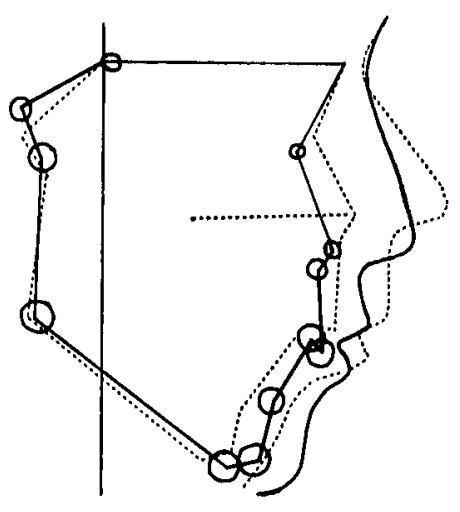

- MEAN

-... PRE DP.

图 2 入院時の Profilogram

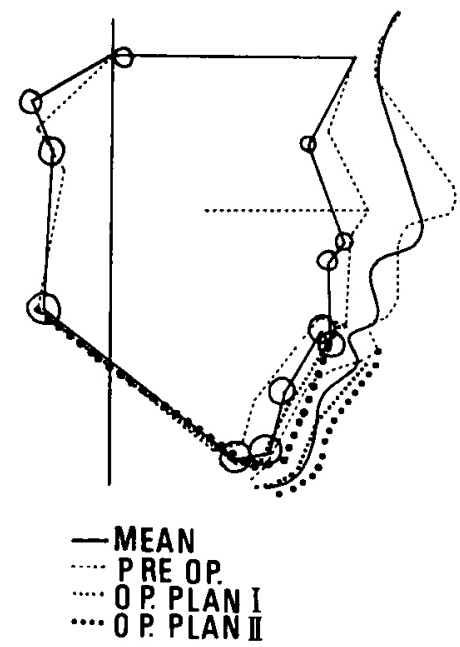

図 3 手街計画を示す Profilogram
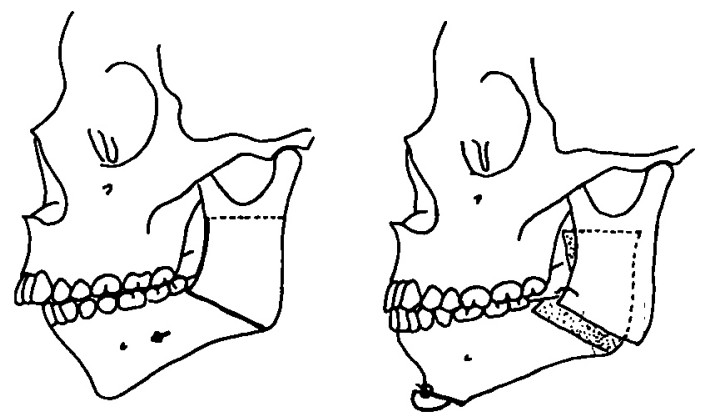

図 4 手得方法

Obwegeser 氏法, Sliding horizontal osteotomy による Genioplasty

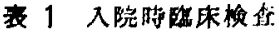

\begin{tabular}{|c|c|c|c|}
\hline \multicolumn{2}{|c|}{ Hematological exam. } & \multicolumn{2}{|c|}{ Blow firfuirial exam. } \\
\hline R.IB.C'. & $446-10^{4}$ & $\mathrm{SC} ; \mathrm{S}$ & $40 \mathrm{mU} / \mathrm{ml}$ \\
\hline 111, & $13.3 \mathrm{~g} / \mathrm{d} l$ & 1.1.H & $120 \mathrm{mU} / \mathrm{ml}$ \\
\hline H & $39.1 \%$ & Alk.phos & $54 \mathrm{mU} / \mathrm{ml}$ \\
\hline W.B.C. & 6,400 & T. Bili. & $0.4 \mathrm{mg} \%$ \\
\hline 'Thrombo. & $29.8 \times 10^{4}$ & Alb. & $4.4 \mathrm{gm} \%$ \\
\hline Bleeding lim. & $2^{\prime} 30^{\prime \prime}$ & I.P. & $7.5 \mathrm{gm} \%$ \\
\hline C'oigulation ti & me $8^{\prime} 30^{\prime \prime}$ & Chol. & $199 \mathrm{mg} \%$ \\
\hline \multirow{5}{*}{\multicolumn{2}{|c|}{ Stdim. rate $19.5(1 \mathrm{hr} .18)$}} & Lne acid & $4.0 \mathrm{mg} \%$ \\
\hline & & $B L X$ & $15 \mathrm{mg} \%$ \\
\hline & & Glu. & $107 \mathrm{mg} \%$ \\
\hline & & Inor. phos. & $3.6 \mathrm{mg} \%$ \\
\hline & & $\mathbf{C a}$ & $9.6 \mathrm{mg} \%$ \\
\hline
\end{tabular}

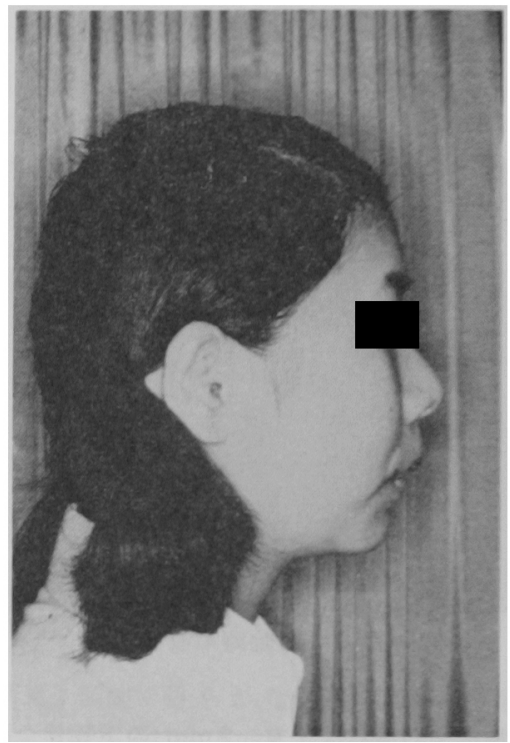

写直 4 徏後 3 か月の湖貌

Convexity 19.20, A-B plane-11.25, Y-Axis 71.55, SNB 77.89，SNA-SNB 11.53 と明らかに良好な結果が

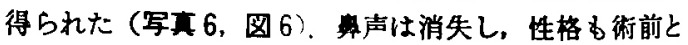
比較して明るくなり，本手術が当患者の心理面化す良い 影繁を与えたことがうかがえる．また，下額骨の近心移 動の術後にしばしばみられる後戻りや下口辰の知覚麻陣 などの障害む認められず，患者の満足を得ている。

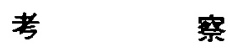

小下頻店(Micrognathia)は，下䫑骨体と下䫑枝の劣成 長によって生じ，買関節強直症症例にみられるような下 

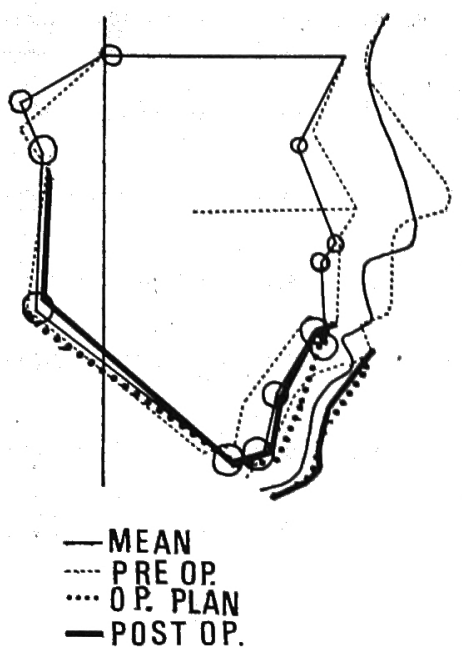

图 5 術後の Profilogram

\section{ROINTEN CEPHAOMETRIC ANALSIS}

CASE NO.: S2Y WE:S T

$$
\text { NEAN SO RESUT }
$$

AGE: 24 SEX:F

FACIA ARE

CONEXITY

7.58 - 4.95 19.8

$\begin{array}{lll}7.81 & 3.50-11.25\end{array}$

ab Plane

$28.815 .23 \quad 39.94$

MARDIBU

$65.78 \quad 5.63 \quad 71.55$

$0.00 \quad 20.0001000$

- wan

$\rightarrow$ POAt op.

$11.42 \quad 3.64 \quad 15.12$

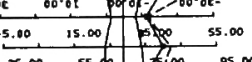

Ocauser ith.

$11.42 \quad 3.64$

15

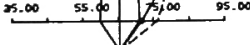

INTERINCIS

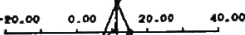

L-1 TO $\propto \mathrm{CCL}$.

124.097 .63119 .06

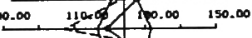

96. 5 3.7日 99.92

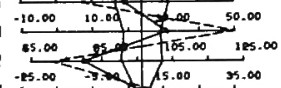

UI T⿱

8.921 .88

0.02

FH TO SN

$6.19 \quad 2.89$

$$
25
$$

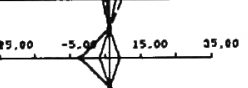

$\sin$

SATSO

82. $32 \quad 3.45 \quad 89.42 \underbrace{50.00,70.00}$

$78.90 \quad 3.4577$. 89 $45.00,45.00,5.00,105.00$

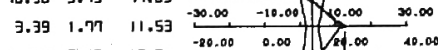

N-1 TO NP

19.71

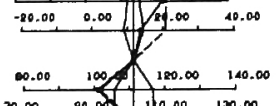

UI TOFH

VI TO SN

BONIAL ARQE

$111.13 \quad 5.54 \quad 100.92$

$+0.00$

$\int_{110.00}^{120.00} 2_{130.00}^{100.00}$

$104.54 \quad 5.55 \quad 102.87$

$122.23 \quad 4.61 \quad 124.33$

90.00

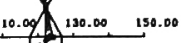

Ranis INCL

$2.93 \quad 4.40 \quad-5.61$

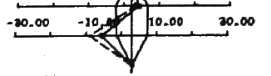

図 6 衡後 3 か月のセファロ分析結果

預枝の発育不全による下㴿骨後退症 (Retrognathia)とは 異なり，一般に先天的または後天的な下顎骨や舌骨の不 均衡な発育によって生じるものとされている。しかし両 症に対する処置は, 同一の方法で行われて括り，オトガ イ部の Osteotomy p骨移植，人工物化よる Implant が しばしば行われている゙かが、オトガイ部のみの移動では 咬合関係の十分な改善が得られないことが多く，骨体部

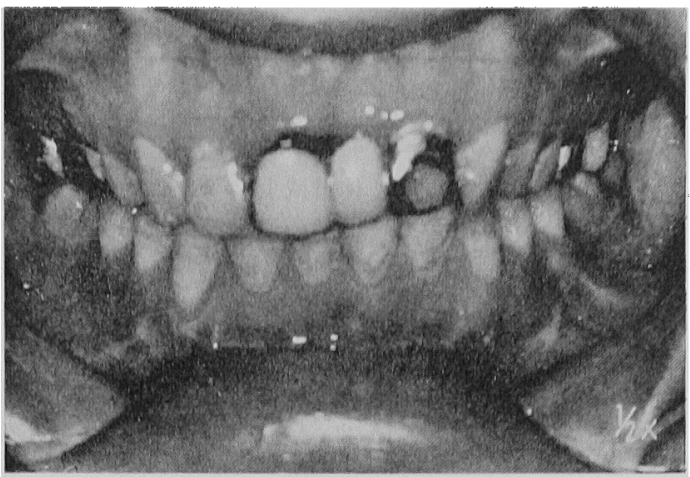

写真 5 微後 3 か月の咬合状態

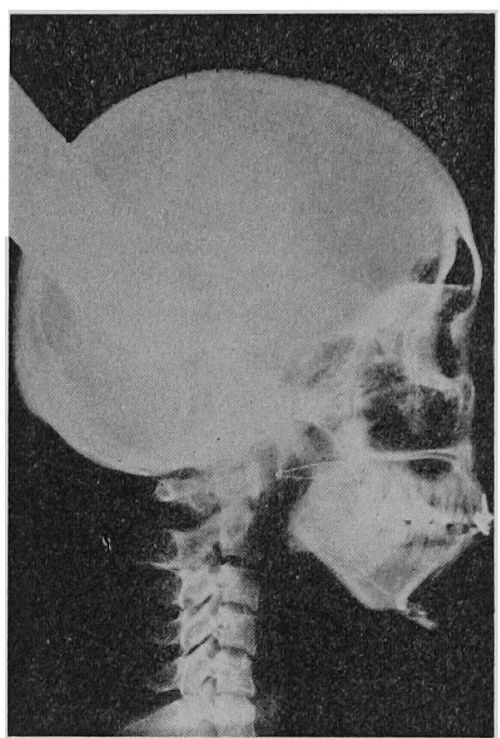

写真 6 術後 3 か月のセファ写真

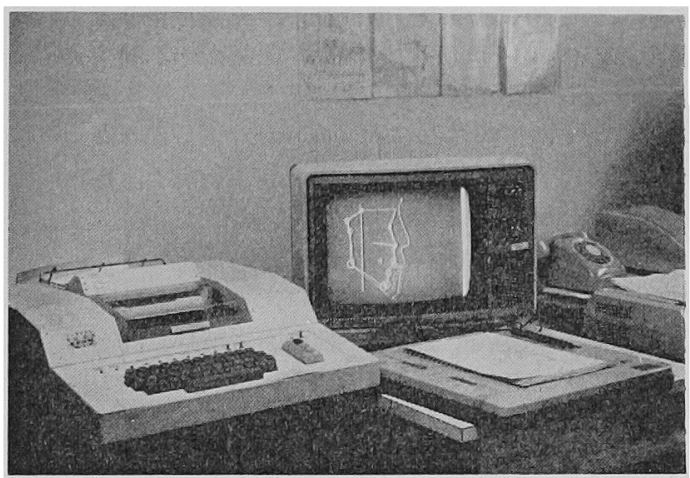

写真 7 解析に用いたマイクロコンピューターシス テムとグラフィックディスプレーに描画さ れた Profilogram 


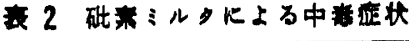

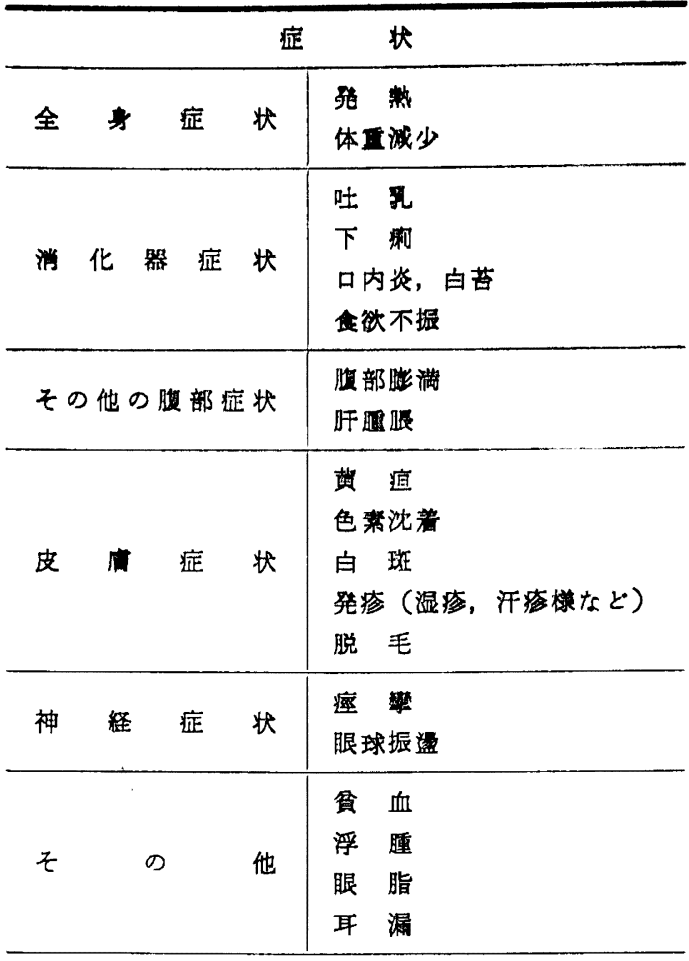

（西田 ${ }^{10)}$ による）

の Step osteotomy ${ }^{5}$ p Kanzanjian らによる L shaped sliding osteotomy ${ }^{6)}$ が行われている。この方法では，白 歯部咬合関係に変化がみられないために，近年下影枝の Osteotomy により下䫇骨を前方に移動する方法7が考案 され，骨移植を行ら下㴿枝の Step osteotomys)などが報 告されている．今回施行した Obwegeser 氏下晾枝矢状 分割法は， 口腔内上りの Approach のために顔面皮成 に洀痕を残さず，骨の接触面積が広くて骨片の適合が容 易なために，小下頻症たけけでなく，開咬㱏や下頻前突症な ど種々なる䫕顔面変形症症例に応用できる手術法”であ る。本例では下顎枝の Osteotomy による前方移動のみ では十分なオトガイの突出が得られないので，さらにオ

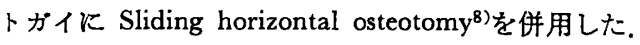

これらの㴿顔面変形症症例に外科的稪正術を施行する 際に, 手術計画の立案は, 一般に, 患者の顔貌の観察, 上下顎歯列模型に上る診査, 顔面および口腔内写真, ハ ノラマ, デンタルX線写真に加えセファロによる診査に よって行われている，従来, 術者の経験によりこれらの 資料をもとに, 䫑骨の移動量の決定や手術後の顔面形態 の予測を行ってきた。

著者らは，術前に撮影したセファロをディジダイザを 用いて18計測点を入力し，マイクロコンピューターによ

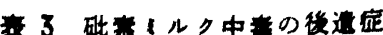

\begin{tabular}{|c|c|c|c|}
\hline 分 敞 & 症侧数 & 1 断 各 & 症体数 \\
\hline 先天箔 & 3 & タクン掟假群 & 3 \\
\hline 柛経 手 & 14 & 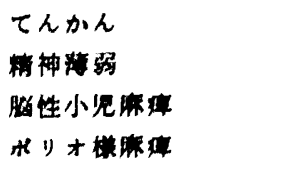 & $\begin{array}{l}9 \\
8 \\
2 \\
1\end{array}$ \\
\hline 消 化 器 & 6 & 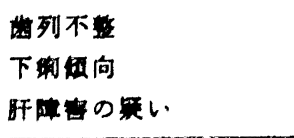 & $\begin{array}{l}2 \\
1 \\
3\end{array}$ \\
\hline 呼吸器 & 3 & 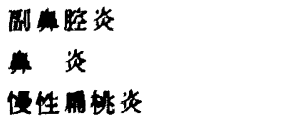 & $\begin{array}{l}1 \\
1 \\
1\end{array}$ \\
\hline 泌尿 器 & 4 & 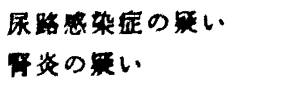 & $\begin{array}{l}2 \\
2\end{array}$ \\
\hline 血 & 15 & 赖 & $\begin{array}{l}7 \\
8\end{array}$ \\
\hline 感 覚 器 & 12 & 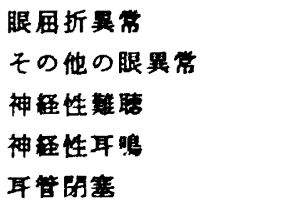 & $\begin{array}{l}6 \\
5 \\
4 \\
1 \\
1\end{array}$ \\
\hline 皮宔 & 21 & 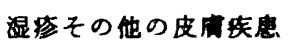 & 21 \\
\hline その 他 & 2 & 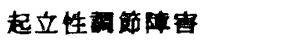 & 2 \\
\hline 著患なし & 7 & & \\
\hline
\end{tabular}

(西田 ${ }^{10}$ 人ょる)

表 4 硕素ミルク中毒览の骨格暴常

\begin{tabular}{|c|c|}
\hline 症 例 & 状 \\
\hline 1 & 短類，右銷骨小，右有变形 \\
\hline 2 & ロート眴，春椎後䈍 \\
\hline 3 & 眴部非奶称，奉椎湖学 \\
\hline 4 & 頭盖小, 青椎㑡管 \\
\hline 5 & 脊椎㑡罗 \\
\hline 6 & 霍椎㑡彎 \\
\hline
\end{tabular}

（西田 ${ }^{10)}$ による）

り， S 点を原点とし， S-N をX軸とする座標に変換し， Profilogram をグラフィックディスブレイ装置に出力さ せ，術前の Profilogram と骨格修正漂準図形および仮想 側貌図形を作成し，標準図形との対比で良好な形態を彷 後に得るための箱骨の䔟動量の決定を行った (写真 7). 
本例では，下顥骨全体の $9 \mathrm{~mm}$ の前方移動では良好な

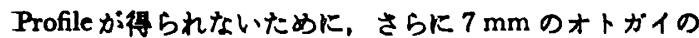
前方移動が必要であることが判明し、これらの䊝勘啳の 顔面形態を示す Profilogram の作成を行った。トレース や角度，距離の計測といった手作菜で行ってきたセつっ 口分析を省力化し，少ない誤差で，短時間に，具体的客 謂的な手術計画の作成と術後の形態予測がコンピュータ ーシステムにより可能になった。

さて本症例は䂤素ミルク中絜認定患者であり，䂤秦中 毒と小下額症との因果関㐿恃不明であるが，吪菜ミルク

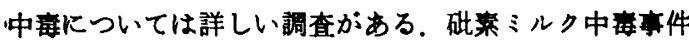
は，1955年に岡山大学法医学数室において，発繁，体重 減少, 消化器症状中その他の腹部症状，皮店症状，神経 症状 ${ }^{10)}$ (表 2）がM社ドライミルクに䂤桑が混入された ことによることが指摘されて以来，その释過の追跡 ${ }^{10,12 ，}$ 13)が㣫々行われており，14年目の後遗症としても神経系 や消化器, 呼吸器, 泌尿器, 血液, 感覚器などにあらわ れたとの報告すみられる ${ }^{10}$ (表 3)。同報告で骨格型の翼 常は47例中 6 例に認められ，春椎側彎を 6 例全例で，頭 蓋顔面部で 1 例に頭蓋の狭少を示したとしている ${ }^{10}$ （表 4).しかしながら，本例のよ5に顥骨の変形をきたした すのは記戴されておらず，歯列不整を 2 例に琶めたと報 告しているがその詳練は不明である。 また，和田の家 鬼14)を用いた砒素中毒の実験では，脛骨骨幹の砒素濃度 は中毒の経過とともに增加し，投与の中止により減少す るが，投与中止後10日目で軟組織は $1 / / \mathrm{g}$ 以下を示すの 飞対して，骨幹では $3 \gamma / \mathrm{g}$ 以上のものが $45 \% て ゙ ， 1.5 \gamma / \mathrm{g}$ 以上のものが80\%を占め脛骨骨端ですほぼ同様であり， 頭蓋骨であ投与中止後10日目で $1.0 \mathrm{r} / \mathrm{g}$ 以上を示し，骨 幹の砒素瀑度と同様な傾向を示したと報告しており，長 管骨長径の発育不全が䂤素中毒より生じるしている。

砣素ミルク中毒览において，本例と同様な下顎骨など の顔面骨の発育不全を呈した症例の報告はいまたみられ ないよらであるが，䫓骨の発育状態や歯牙の石灰化の問 題など硬組織発有に対する吪素中毒の影遙についてさら 飞詳細な検討を行う必要があると思われた。

\section{む す び}

1）砒素ミルク中毒患者で，小下顠症を呈した症 例 (24歳，女性）に対して，側方頭部X線規格写真をマイク ロコンピューターシステムにより分析, 手術計画を立案 乙，下影枝矢状分割法 (Obwegeser 氏法)と Genioplasty ひよる顎形成術を施行して良好な結果を得た 1 例を経験 した.

2) 䪽顔面変形症症例の診断, 手術計画, 術後の形態 予測に関してマイクロコンピューターを応用して，分析 時間を短粳, 省力化し, 術後形態を具体的, 客観的に把 握することができた。
3）很後約 1 か年半を経た現在，きわめて順珮な経過 をたどり，また心理面に打いても性格が明るくなるなど 良好な絬果が得られた。

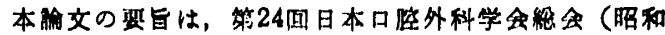
54年10月 5 日) に扎いて器した。

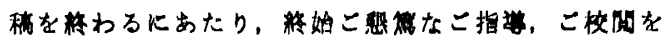

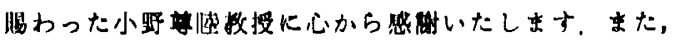
コンピューターの初频から Programing までこ指導，こ

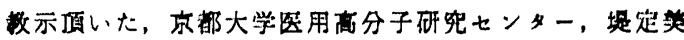
博士に原く扰礼电し上げます。

\section{引用文 献}

1）花田晃治：下颖前㔖の外科的矮正。第1 版，株 式会杜害林，東京，1977，65頁。

2）兵行忠，他：多变量解析に上万影变形症の

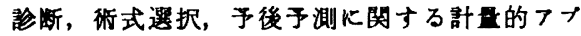
口一千。旺外誌 27：1 1981.

3) Obwegeser, H.L.: The indication for surgical correction of mandibular deformity by the sagittal splitting technique. Brit J Oral Surg 1: 1571964.

4) Hinds, C.E., Kent, J.H.: Surgical treatment of developmental jaw deformities. ed I, Mosby Co, St Louis, 1972, P 96.

5) Limberg, A.A.: New method of plastic lengthning of the mandibule in unilatelar microgenia and asymmetry of face. JADA 15: 8511928.

6) Kanzanjian, V.H.: Surgical correction of deformities of jaw and its relation to orthodontia. Am J Orthodont 22: 2591936.

7) Blair, V.P.: Underdeveloped lower jaw, with limited excursion. JAMA 53: 1781909.

8) Trauner, R, \& Obwegeser, H.L.: The surgical correction of mandibular prognathism and retrognathia with consideration of genioplasty. Oral Surg 10: 8991957.

9）高橋庄二郎，他：下䫑枝矢状分割法に上万下䫑 前突症手佈について。 日外誌 17：524 1971 .

10）西田勝, 他：森永七慗ミルク中毒症追跡調查 中間報告(小児科)。医学のあゆみ 74:1 1970.

11）浜本英次，他：粉乳に上る乳児䂤素中毒症. 日 本医事新報 1649: 31955.

12）永井秀夫，他：乳児にみられた亜急性乃至慢性 「砣素中毒」一最近 2 力月間の臨床観察一。 小 児科紀要 1: 2281955.

13）湯浅亮一：昭和 30 年の森永砣素ミルクに上る被 炎児の精神神経学的現症。医学のあゆみ 74:14 1970.

14）和田久一：砒素中毒に関する実験的研究，第 3 編 亜急性砒素中毒に於ける骨, 特飞骨端の䂤 素溚度について。少科紀要 4:59 1958. 